\title{
THE DEVELOPMENT OF STUDENT WORKSHEET BASED ON CORE (CONNECTING, ORGANIZING, REFLECTING AND EXTENDING)
}

\author{
Ririn Eva Hidayati \\ MAN 1 Kota Malang \\ ririneva@gmail.com
}

\begin{abstract}
The purpose of this research to determine the feasibility of student worksheet base on CORE (connecting, organizing, reflecting and extending) based on the validation data with the data source chemistry teacher and student responses to the data source. The design used was a model Research and Development $(R \& D)$, where there is a stage and potential problems, data collection, design, study, revision, validation, and test student worksheet base on CORE. The results of the study design was tested in the validation and limited so that it will produce a student worksheet base on CORE in accordance with the standards of eligibility based on the feasibility of the content or materials, presentation and language. Student worksheet base on CORE that was developed has been validated by two chemistry lectures and three teachers of chemistry and tested on 34 MAN 1 Kota Malang students. Achievement of the feasibility of the student worksheet base on CORE is the percentage of the overall aspects of the chemistry teacher assessment to validate that is equal to $98.15 \%$, while the percentage of student responses obtained at $98.52 \%$.
\end{abstract}

Keywords: Student worksheet, CORE, learning achievement

\section{PENDAHULUAN}

Pendidikan merupakan salah satu upaya untuk meningkatkan kualitas sumber daya manusia. Dalam rangka peningkatan kualitas tersebut, siswa di berbagai jenjang pendidikan dibekali bermacam-macam ilmu pengetahuan, salah satunya adalah ilmu kimia.

Kimia merupakan salah satu cabang ilmu sains yang sangat penting [1]. Ilmu kimia mengkaji adanya fakta yang dipelajari melalui observasi atas gejala-gejala alam maupun suatu kerja ilmiah yang menghasilkan suatu konsep dalam bentuk hukum dan teori. Pemahaman konsep yang ada ini dapat dibangun siswa secara mandiri maupun dengan bimbingan guru. Baik guru maupun siswa dapat menggunakan bahan ajar yang sudah ada untuk membatu proses pembelajaran dan pemahaman materi kimia.

Dalam Peraturan Pemerintah nomor 19 tahun 2005 Pasal 20 disebutkan bahwa guru diharapkan mengembangkan materi pembelajaran. Hal ini juga dipertegas melalui Peraturan Menteri Pendidikan Nasional (Permendiknas) nomor 41 tahun 2007 tentang Standar Proses, yang antara lain mengatur tentang perencanaan proses pembelajaran yang mensyaratkan bagi pendidik pada satuan pendidikan untuk mengembangkan rencana pelaksanaan pembelajaran (RPP). Salah satu elemen dalam RPP adalah sumber belajar [2].

Bahan ajar merupakan komponen pendukung yang penting dalam usaha pencapaian tujuan pembelajaran. Bahan ajar yang biasa digunakan guru sebagai rujukan dalam mengajar adalah buku paket, LKS, dan buku referensi lainnya yang relevan. Berdasarkan hasil observasi sebagian guru menyatakan bahwa membuat bahan ajar merupakan pekerjaan yang sulit dan memakan waktu serta tenaga yang tidak sedikit.

Beberapa materi dalam pelajaran kimia sulit dipahami oleh siswa ataupun sulit dijelaskan oleh guru. Kesulitan tersebut terjadi karena kimia mencakup kajian yang konseptual dan konsep-konsep yang abstrak $[1 ; 3]$.

Reid menyatakan bahwa materi yang berhubungan dengan perhitungan dan mol merupakan materi yang dianggap sulit oleh siswa [3]. Hal ini juga didukung oleh hasil penelitian yang menyatakan bahwa konsep 
mol merupakan salah satu materi yang kompleks dalam kimia yang membuat kebanyakan siswa merasa kesulitan mempelajari kimia [4].

Pokok bahasan konsep mol sangat perlu diajarkan dengan baik karena pokok bahasan konsep mol merupakan salah satu materi dasar dan prasyarat untuk mempelajari materi-materi kimia selanjutnya terutama materi-materi yang menyangkut perhitungan kimia. Siswa kelas X SMA seharusnya dapat menguasai materi pokok konsep mol dengan baik, sehingga dapat digunakan sebagai bekal untuk belajar kimia lebih lanjut. Kelemahan dan keberhasilan siswa dalam memahami konsep mol ini sangat berpengaruh untuk penguasaan konsep kimia berikutnya.

CORE Learning menyertakan empat tahap pembelajaran yaitu Connecting, Organizing, Reflecting, dan Extending. Tahapan tersebut dapat digunakan untuk mengonstruksi pemahaman siswa melalui urutan instruksi selama aktivitas pembelajaran berlangsung. Pertama, siswa dihubungkan dengan fakta yang ditemuinya dalam kehidupan sehari-hari dengan topik yang ada dalam pembelajaran sains. Selanjutnya, siswa mengorganisasi informasi tersebut menjadi suatu konsep dasar. Kemudian, siswa melakukan refleksi dari masalah yang muncul pada konsep dasar dan mendiskusikannya dalam kelompok diskusi. Terakhir, siswa dapat mengembangkan konsep tersebut pada cakupan masalah yang lebih luar lagi [5]. CORE diharapkan menjadi salah satu solusi untuk meningkatkan pemecahan masalah matematis siswa [6].

Atas dasar permasalahan di atas, peneliti terdorong untuk mengembangkan lembar kerja siswa (LKS) berbasis CORE yang dapat menunjang proses pembelajaran kimia. Adapun materi yang dipilih untuk dikembangkan adalah materi konsep mol.

\section{METODE}

Pengembangan media pembelajaran ini mengacu pada metode penelitian Research and Development (R\&D) Borg dan Gall. Langkahlangkah research and development ( $\mathrm{R} \& \mathrm{D})$ Borg dan Gall seperti disajikan pada Gambar 1.

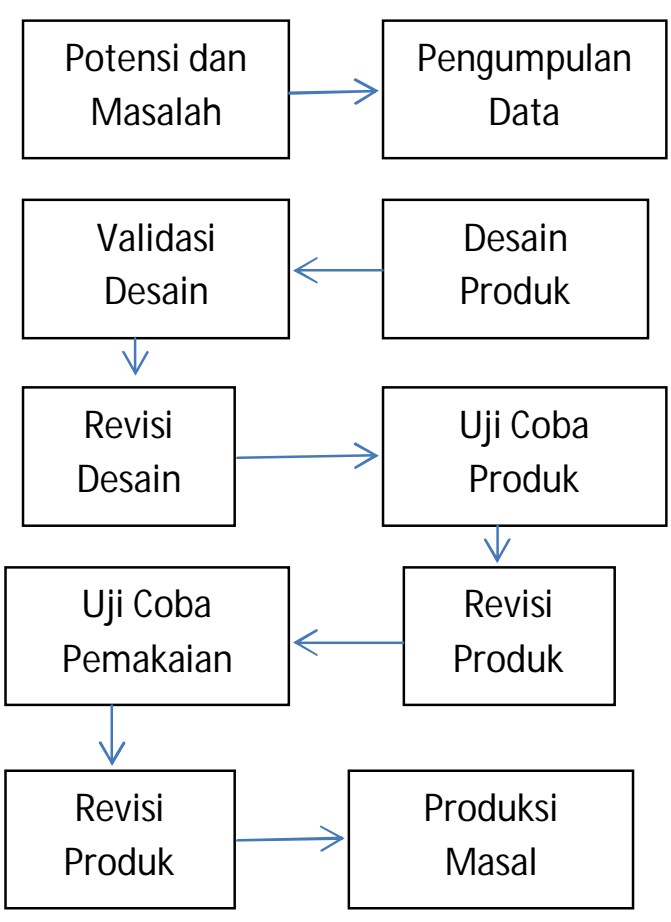

Gambar 1. Alur Pengembangan LKS berbasis CORE

\section{HASILDAN PEMBAHASAN}

\section{Potensi dan Masalah}

Berdasarkan hasil dari review lembar kerja siswa (LKS) yang ada cenderung berisi materi dan soal saja yang mungkinmemunculkan kebosanan siswa dan membuat siswakurang berminat untuk belajar. Hal tersebutdidukung oleh angket respon siswayang menunjukkan bahwasiswa merasa kesulitan dengan materi konsep mol.

\section{PengumpulanData}

Data yang dikumpulkan adalah kurikulum 2013, buku paket serta hasil review lembar kerja siswa (LKS).

\section{Desain Produk}

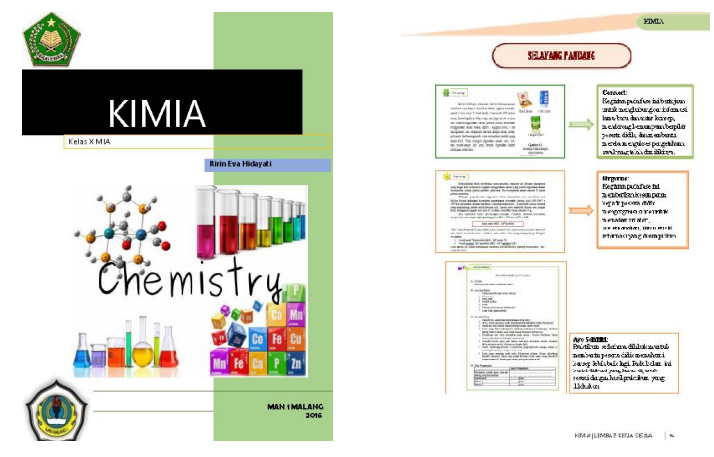




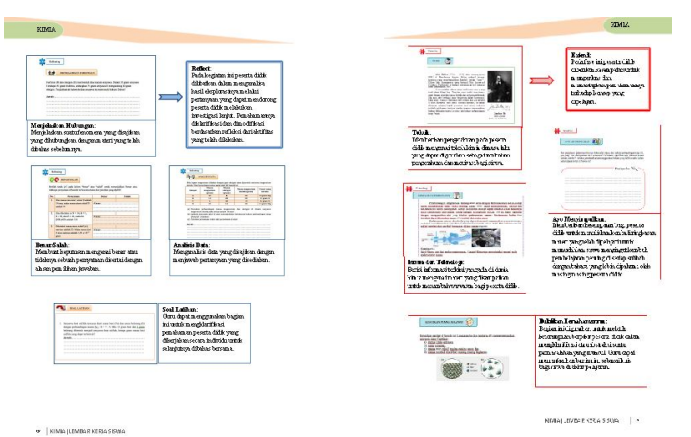

Gambar 2. Tampilan LKS berbasis CORE

\section{Validasi dan Revisi}

Validasi terhadap lembar kerja siswa (LKS) berbasis CORE dilakukan dua orang dosen kimia Universitas Negeri Malang dan tiga guru kimia MAN 1 Kota Malang. Validasi dilakukan dengan tujuan untuk mengetahui kelayakan lembar kerja siswa (LKS) berbasis CORE yang dikembangkan dari segi kelayakan isi, bahasa dan penyajian.

Hasil validasi dari para validator memberikan nilai $98,15 \%$, hasil ini menunjukkan bahwa lembar kerja siswa (LKS) berbasis CORE yang dikembangkan layak digunakan dalam proses pembelajaran. Respon yang diberikan siswa sebesar 98,52\% yang menyatakan bahwa lembar kerja kiswa (LKS) berbasis CORE layak digunakan dalam proses pembelajaran.

5. Hasil Belajar Siswa

Hasil pretest dan postest disajikan dalam tabel 1.

Tabel 1. Hasil Pretest dan Postest

\begin{tabular}{clcc}
\hline No & \multicolumn{1}{c}{ Nama } & Pretest & Postest \\
\hline 1 & AIDA F B & 80 & 88 \\
2 & ALYA RAHMA & 92 & 97 \\
3 & ANDANIA ULFA & 28 & 81 \\
4 & ASHLIHATUL H & 76 & 84 \\
5 & ASSYIFA S & 72 & 91 \\
6 & AULA F Z & 84 & 84 \\
7 & AURIA NURUL H & 72 & 94 \\
8 & AZZAHRA A A & 52 & 72 \\
9 & DEWI EKA M & 84 & 94 \\
10 & DINI HIDAYATUL & 64 & 78 \\
11 & DYAH ARDINI N S & 80 & 94 \\
12 & ELVINA DWI F & 52 & 78 \\
13 & FARIKHATUL M & 72 & 84 \\
14 & FIFI RAHMAWATI & 76 & 97 \\
15 & HAURA SALWA A & 60 & 81
\end{tabular}

\begin{tabular}{|c|c|c|c|}
\hline 16 & IMELIA DAELI & 68 & 97 \\
\hline 17 & ISNA MEIRILLAH & 92 & 91 \\
\hline 18 & ISTIGHFARIN M A & 60 & 88 \\
\hline 19 & LAILATUL IZATA & 64 & 91 \\
\hline 20 & MAGITA E M & 80 & 91 \\
\hline 21 & MAULIDYA R P & 44 & 59 \\
\hline 22 & NABILA ALIFA S & 88 & 97 \\
\hline 23 & NADIA NAHDA & 48 & 63 \\
\hline 24 & NIDAUD DIANA & 52 & 56 \\
\hline 25 & ORYZA S ASHARI & 56 & 69 \\
\hline 26 & RAHMADIYANTI & 76 & 81 \\
\hline 27 & RIZKI IRA SINDI & 52 & 63 \\
\hline 28 & SABILLA PUTRI & 48 & 81 \\
\hline 29 & SHELBI SURURIN & 56 & 81 \\
\hline 30 & SONIA AISYAH & 24 & 78 \\
\hline 31 & SYARIFAH NUR & 76 & 81 \\
\hline 32 & 'TSANIYA ZAHRO' & 80 & 84 \\
\hline 33 & ZAHRAH Z & 60 & 72 \\
\hline 34 & ZAYYAN SH & 72 & 78 \\
\hline & Total & 2240 & 2798 \\
\hline & Rata-Rata & 65,88 & 82,29 \\
\hline
\end{tabular}

Pembelajaran berbasis CORE efektif dalam meningkatkan hasil belajar siswa dikarenakan tahapan-tahapan yang diwarkan dalam kegiatan pembelajaran disesuaikan dengan taraf perkembangan kognitif siswa yaitu tahap operasional formal, suatu tahap dimana siswa sudah dapat berpikir secara abstrak/simbolik dan menyelesaikan masalah dengan menggunakan eksperimen. Menurut Piaget pembelajaran yang dirancang dan dilaksanakan dengan menyesuaikan kemampuan dan karakteristik siswa akan menjadi lebih bermakna [7]. Pembelajaran yang bermakna bagi siswa berdampak positif terhadap kemajuan belajar.

\section{SIMPULAN DAN SARAN}

Berdasarkan hasil penelitian dapat disimpulkan bahwa:

1. Peneliti telah berhasil mengembangkan lembar kerja siswa berbasis CORE.

2. Lembar kerja siswa berbasis CORE layak dan sangat bermanfaat dalam pembelajaran kimia. 


\section{DAFTAR PUSTAKA}

[1] Sirhan, Ghassan. (2007). "Learning difficulties in chemistry: An overview." Journal of Turkish Science Education, 4(2), 2-20.

[2] Direktorat Pembinaan Sekolah Menengah Atas. (2008). Panduan Pengembangan Bahan Ajar. Jakarta: Departemen Pendidikan Nasional.

[3] Reid, N. 2008. A Scientific Approach to the Teaching of Chemistry. Chemistry Education Research and Practice, 9: 5159.

[4] Gulacar, Overton, \&Bowman. (2013). A Novel Code System for Revealing Sources of Students' Difficulties with Stoichiometry. Chemistry Education Research and Practice. Issues 4.

[5] Calfee, R.C. \& Miller, R.G. 2004. Making Thinking Visible: A Method to Encourage Science Writing in the Upper Elementary Grades. Science and Children, (Online), 42(3): 20-25, (www.roxannegmiller.com), diakses 31 Agustus 2015.
[6] Kumalasari, E. 2011. Peningkatan Kemampuan Pemecahan Masalah Matematis Siswa SMP Melalui Pembelajaran Matematika Model CORE. Prosiding disampaikan pada Seminar Nasional Pendidikan Matematika STKIP Siliwangi Bandung, Bandung 2011. Dalam Publikasi STKIP Siliwangi, (Online),

(http://www.google.co.id/url?q=http://pub likasi.stkipsiliwangi.ac.id/files/2012/11/El lisia-Kumalasari.pdf), diakses 02 September 2015.

[7] Zidny, R. Sopandi, W. \& Kusriajadi, A. 2013. Analisis Pemahaman Konsep Siswa SMA Kelas X pada Materi Persamaan Kimia dan Stoikiometri Melalui Penggunaan Diagram Submikroskopik serta Hubungannya dengan Kemampuan Pemecahan Masalah. Jurnal Riset dan Praktik Pendidikan Kimia, 1(1): 27-36. 